\title{
BMJ Open Effect of rapid HIV testing on HIV incidence and services in populations at high risk for HIV exposure: an equity-focused systematic review
}

Kevin Pottie, ${ }^{1,2,3,4,5}$ Olanrewaju Medu, ${ }^{3}$ Vivian Welch, ${ }^{2,4,6,7}$ Govinda P Dahal, ${ }^{2,8}$ Mark Tyndall, ${ }^{3,4}$ Tamara Rader, ${ }^{2}$ George Wells ${ }^{3,5}$

To cite: Pottie K, Medu 0, Welch $\mathrm{V}$, et al. Effect of rapid HIV testing on HIV incidence and services in populations at high risk for HIV exposure: an equity-focused systematic review. BMJ Open 2014;4: e006859. doi:10.1136/ bmjopen-2014-006859

- Prepublication history and additional material is available. To view please visit the journal (http://dx.doi.org/ 10.1136/bmjopen-2014006859).

Received 9 October 2014 Accepted 10 November 2014

CrossMark

For numbered affiliations see end of article.

Correspondence to Dr Kevin Pottie; kpottie@uottawa.ca

\section{ABSTRACT}

Objective: To assess the effects of rapid voluntary counselling and testing (VCT) for HIV on HIV incidence and uptake of HIV/AIDS services in people at high risk for HIV exposure.

Design: Cochrane systematic review and metaanalysis.

Data sources: We searched PubMed, EMBASE, AIDSearch, LILACS, Global Health, Medline Africa, PsychInfo, CINAHL, Cochrane CENTRAL, Cochrane HIV/AIDS Group Specialized Register and grey literature from 1 January 2001 to 5 June 2014 without language restriction.

Data selection: We included controlled studies that compared rapid VCT with conventional testing among people at risk for HIV exposure.

Data extraction: Two reviewers extracted data. We used Cochrane risk of bias tool and GRADE criteria: risk of bias, inconsistency, indirectness, imprecision and publication bias. For observational studies we used the Newcastle-Ottawa Scale. We used the PRISMAEquity reporting guideline.

Results: From 2441 articles, we included 8 randomised controlled trials and 5 observational studies. Rapid VCT was associated with a threefold increase in HIV-testing uptake (relative risk (RR) $=2.95$ $95 \% \mathrm{Cl} 1.69$ to 5.16 ) and a twofold increase in the receipt of test results ( $R R=2.14,95 \% \mathrm{Cl} 1.08$ to 4.24 ). Women accepted testing more often than men in rapid VCT arm, but no differences in effect for age or socioeconomic status. Observational studies also showed rapid VCT led to higher rates of uptake of testing. Heterogeneity was high. A cluster-randomised trial reported an $11 \%$ reduction in HIV incidence in intervention communities ( $\mathrm{RR}=0.89,95 \% \mathrm{Cl}=0.63$ to 1.24) over 3 years trial.

Conclusions: Rapid VCT in health facilities and communities was associated with a large increase in HIV-testing uptake and receipt of results. This has implications for WHO guidelines. The routine use of rapid VCT may also help avoid human rights violations among marginalised populations where testing may occur without informed consent and where existing stigma may create barriers to testing.

\section{Strengths and limitations of this study}

- This Cochrane systematic review included randomised controlled trials (RCTs) and observational studies from four continents and included a range of groups at high risk for HIV exposure.

- This review included rapid voluntary counselling and testing (VCT) interventions from health facilities and community-based interventions.

- RCTs showed that rapid VCT was associated with a large increase in HIV-testing uptake and receipt of results but these studies did not report on antiretroviral treatment.

- Observational studies showed increased acceptance of HIV testing and did not show age, sex or income differences.

- Across the studies there was significant heterogeneity likely due to variations in settings and implementation.

- We found only a small number of RCTs (seven) and comparisons were limited for the various rapid VCT interventions with significant heterogeneity likely due to setting and implementation setting differences.

\section{INTRODUCTION}

HIV counselling and testing is the starting point for treatment and care and play a key role in the UNAIDS' 'Getting to zero' strategy. ${ }^{1}$ According to 2012 UNAIDS data, about $50 \%$ of people living with HIV are unaware of their diagnosis. ${ }^{1-3}$ Delays in diagnosis result in lost opportunity for prevention and treatment, resulting in poorer health outcomes. ${ }^{4-6}$ While early diagnosis and treatment has been shown to improve clinical outcomes, quality of life and economic productivity. ${ }^{7-9}$

HIV remains a disease of public health importance. ${ }^{10}$ Recently, outbreaks have been identified in people who inject drugs in North America, Europe and parts of 
Australia. $^{11} 12$ A disparate proportion of new infections in the USA is accounted for by youth, African-American, Latino as well as Aboriginal populations who are also less likely to get tested, receive results, access and remain in HIV care. ${ }^{13-15}$ The disease continues to be fuelled by unsafe sexual practice between and within sexes. ${ }^{16}$ These inequities are associated with HIV-related stigma, fear, financial constraints, transportation and system barriers, and a lack of supports within marginalised communities. ${ }^{17-22}$

Conventional testing, ordering an HIV blood test and having the patient return for results, has not performed well in marginalised communities. ${ }^{13}{ }^{14}$ Persons at high risk for HIV exposure include persons who inject drugs, men who have sex with men, persons from HIV epidemic countries (prevalence $>1 \%$ ), street youth, pregnant women, sex workers, low-income and socially disadvantaged people, Aboriginal persons, and other minorities. $^{18} 19{ }^{23}$ Alternative HIV counselling and testing strategies have emerged to improve uptake of services in these populations. These include home-based, work-based and parole office-based testing, peer-based and community-based (CB) voluntary counselling and testing (VCT), mobile testing and universal population testing. $^{24}$ Improved update was documented in a Cochrane review on home-based testing and a trial on workplace testing. ${ }^{26} 27$

The accuracy of rapid HIV tests is now approaching that of laboratory-based ELISA and western blot testing. ${ }^{28}$ A variety of rapid-test kits exist ranging from oral kits to single use blood drop-based kits. In highincome countries $\mathrm{CB}$ rapid VCT may cost up to four times more than facility-based testing. ${ }^{29}$ Research however, from low-income, high-prevalence settings suggests CB rapid VCT is cost-effective. ${ }^{30} 31$ Greater costeffectiveness is associated with outreach-based programmes that use rapid VCT rather than conventional testing. $^{30}{ }^{32}$ Others have argued that rapid VCT approaches linked to treatment programmes optimise uptake of treatment for high-risk populations. ${ }^{33-35}$ Very few systematic review explicitly report on equity. In order to study the effect of rapid VCT on high-risk populations we used an equity-focused systematic review approach to identify, extract and synthesise evidence on equity.

Rapid VCT is a complex intervention aimed to increase the participation of marginalised populations in HIV testing and treatment programmes. Rapid VCT consists of three components: (1) voluntary enrolment, (2) rapid testing (results within $24 \mathrm{~h}$ ) and (3) counselling and delivery of results and treatment options. A recent systematic review on home-based testing synthesised 19 observational studies from sub-Saharan Africa found the vast majority of participants accepted testing, however comparison groups were limited. ${ }^{36}$ Another systematic review of mainly observational studies showed $66 \%$ increase in uptake of testing among pregnant Kenyan women in antenatal clinics with rapid VCT. ${ }^{37}$ Thornton et $a l^{38}$ assessed feasibility, acceptability and effectiveness of HIV-testing strategies in high-income countries and reported high overall client satisfaction and positive staff attitudes towards CB testing but called for more data to evaluate the actual strategies, confidentiality concerns and post-test counselling. The 2013 WHO HIV guidelines recommend $\mathrm{CB}$ and other HIV testing be done in conjunction with treatment and counselling, but they do not define the critical components of the testing to treatment intervention. ${ }^{39}$ In order to effectively scale up HIV testing, treatment and viral load suppression more precise knowledge is needed to guide interventions for people at high risk for HIV exposure.

\section{METHODS}

\section{Primary objective}

The aim of our review was to assess the effects of rapid VCT on the following HIV-related outcomes for populations at high risk for HIV exposure: (1) uptake, (2) receipt of results, (3) repeat testing, (4) HIV incidence compared with conventional laboratory testing approaches and (5) stigma.

This review is reported according to the Preferred Reporting Items for Systematic Reviews and Meta-Analyses-Equity Extension (PRISMA-E) 2012 reporting guideline for equity-focused reviews. ${ }^{40}$ The review protocol was peer reviewed and published on the Cochrane Database of Systematic Reviews. ${ }^{41}$

\section{Search methods}

We searched PubMed via NLM, EMBASE via OVID, AIDSearch via the web, LILACS via the web, Global Health, Medline Africa, PsychInfo via OVID, CINAHL via EbscoHost, Cochrane CENTRAL via Wiley, Cochrane HIV/AIDS Group Specialized Register, abstracts of important meetings (eg, International AIDS Conference) and AIDS specialty journals. We also contacted experts for unpublished research, trials and dissertations along with trial registers of HIV/AIDS Cochrane Centre and the Cochrane Infectious Diseases review group. All database searches were from 1 January 2001 to 5 June 2014. Details of the search strategy are listed in online supplementary appendices 1-3.

\section{Study selection}

After identification of relevant studies and removal of duplicates, two reviewers screened titles and abstracts. Two reviewers then screened full text of relevant articles to determine whether they met eligibility criteria. When disagreements arose, they were resolved with a third reviewer. We contacted authors for additional information when needed.

\section{Data abstraction and selection}

Two authors using pretested standard forms independently extracted data including study details, study characteristics, interventions and intervention effects (HIV uptake of testing, HIV incidence and uptake into 
treatment programmes including the reported measures of association). In addition, we sought information on age, sex, minority status and socioeconomic status (SES).

\section{Eligibility criteria}

We included studies that met the following criteria.

Population: Those focused on marginalised populations at high risk for HIV exposure (as defined earlier).

Intervention: We included studies that met the criteria for rapid VCT with three main components: (1) facilitated voluntary enrolment; (2) use of a rapid-testing approach (providing results within $24 \mathrm{~h}$ ) and (3) outreach counselling, delivery of results and treatment options. Use of the rapid test alone was not sufficient to be considered a rapid VCT.

Comparison: We included 'conventional approaches', which could include one or more of the above elements, but not all three. 'Conventional approaches' refers to HIV testing in health facilities using traditional laboratory testing approaches where the client has to wait for more than $24 \mathrm{~h}$ before results are received.

Study designs: Randomised controlled trials (RCTs), interrupted time series, prospective or retrospective cohort studies and controlled before and after designs that met the above eligibility criteria.

Outcomes of interest include uptake of HIV testing, receipt of HIV tests, repeat HIV testing or retesting, ${ }^{42}$ HIV incidence and HIV-related stigma.

\section{Assessment of study quality and data synthesis}

We assessed risk of bias for the randomised trials using the Cochrane risk of bias tool. ${ }^{43}{ }^{44}$ Studies were judged to be low, high or unclear risk of bias.

The included studies vary with respect to the intervention duration, type and settings. We undertook the analysis using the intention-to-counsel and screen principles including all participants in the study arm to which they were originally allocated. We used Review Manager V.5.2 (The Cochrane Collaboration, Oxford, UK) to aggregate data for each outcome using a random effects model. We chose the random effects model to control for unobserved heterogeneity that we assumed would exist among the included studies. We present all pooled effect estimates as relative risks (RR) with $95 \%$ CIs. We tested for study heterogeneity using the $\mathrm{I}^{2}$ statistic. We did a sensitivity analysis for gender, SES and education level. A summary of findings table was produced showing relative and absolute effects using GRADE Pro (V.3.6 for Windows). In addition, we conducted a GRADE (Grading of Recommendations Assessment, Development and Evaluation) evidence assessment and profile for each selected outcome.

For cluster-randomised studies, we checked whether studies were adjusted for clustering in the statistical analysis. If results were not adjusted, we adjusted them using the variance inflation factor, as described in section 8.11.2.3 of the Cochrane Handbook. ${ }^{45}$ We used an intracluster correlation coefficient (ICC) factor of 0.026 obtained from a previous HIV-related study conducted in Zambia. ${ }^{46}$ The design effect was calculated using the formula: $1+$ (cluster size 1$) \times$ ICC).

For the observational studies, we appraised studies using the Newcastle-Ottawa Scale (NOS) for assessing the quality of non-randomised studies and report the individual study cohort star template. ${ }^{47}$

\section{RESULTS}

\section{Study selection}

The search resulted in 2441 records and 13 met our inclusion criteria (see figure 1). ${ }^{20} 29{ }^{48-57}$ All randomised trials and observational studies were conducted among populations at high risk for exposure and compared rapid VCT with conventional testing. Intervention descriptions and quality assessment of the randomised trials included in the quantitative analysis are shown in tables $1-3 .^{20} 48-5257$

One cluster RCT of 16-32-year-olds also referred to as Project Accept in South Africa, Tanzania, Zimbabwe and Thailand examined community-mobilisation/outreach, mobile rapid testing and post-test counselling compared with conventional VCT on uptake of tests, retesting and incidence of HIV ${ }^{20}$ Another RCT looked at incidence of testing between rapid VCT versus convention testing in men from sexually transmitted disease (STD) clinics in Australia. ${ }^{58}$ An RCT looked at rapid VCT versus conventional testing in women in an antenatal clinic in Kenya and looked at receipt of results and uptake of treatment. ${ }^{50}$ An RCT in US emergency departments (ED) looked at a HIV counsellor-facilitated rapid VCT versus rapid testing by ED staff (laboratory technicians) on testing uptake. ${ }^{48}$ A cluster RCT looked at rapid VCT in home setting compared with conventional testing in Uganda. ${ }^{51}$ Another RCT in the USA looked at the effect of nurse-facilitated rapid VCT versus conventional testing on HIV-testing rates in veterans' affairs hospital. ${ }^{49}$ The final RCT conducted among high-risk populations at a needle exchange programme and bathhouses in the USA examined four alternative testing approaches and assessed the effect on uptake of testing. ${ }^{52}$

We found data on the following outcomes: uptake of testing ( $n=5$ studies), receipt of HIV test results $(n=3$ studies), HIV incidence ( $n=1$ study), repeat testing $(n=1$ study) and stigma ( $\mathrm{n}=1$ study).

Observational studies included four cohort studies. A description and appraisal of the studies and main outcomes is provided in tables 4 and $5 .^{29} 53-56$

\section{Unit of analysis issues}

Our analysis included three cluster-randomised trials and we adjusted these clusters using the methods described in section 8.11.2.3 of the Cochrane Handbook. ${ }^{45}$ We used the ICC derived from a Zambian HIV study. ${ }^{46}$ Adjustments were not made for the individually randomised studies. 


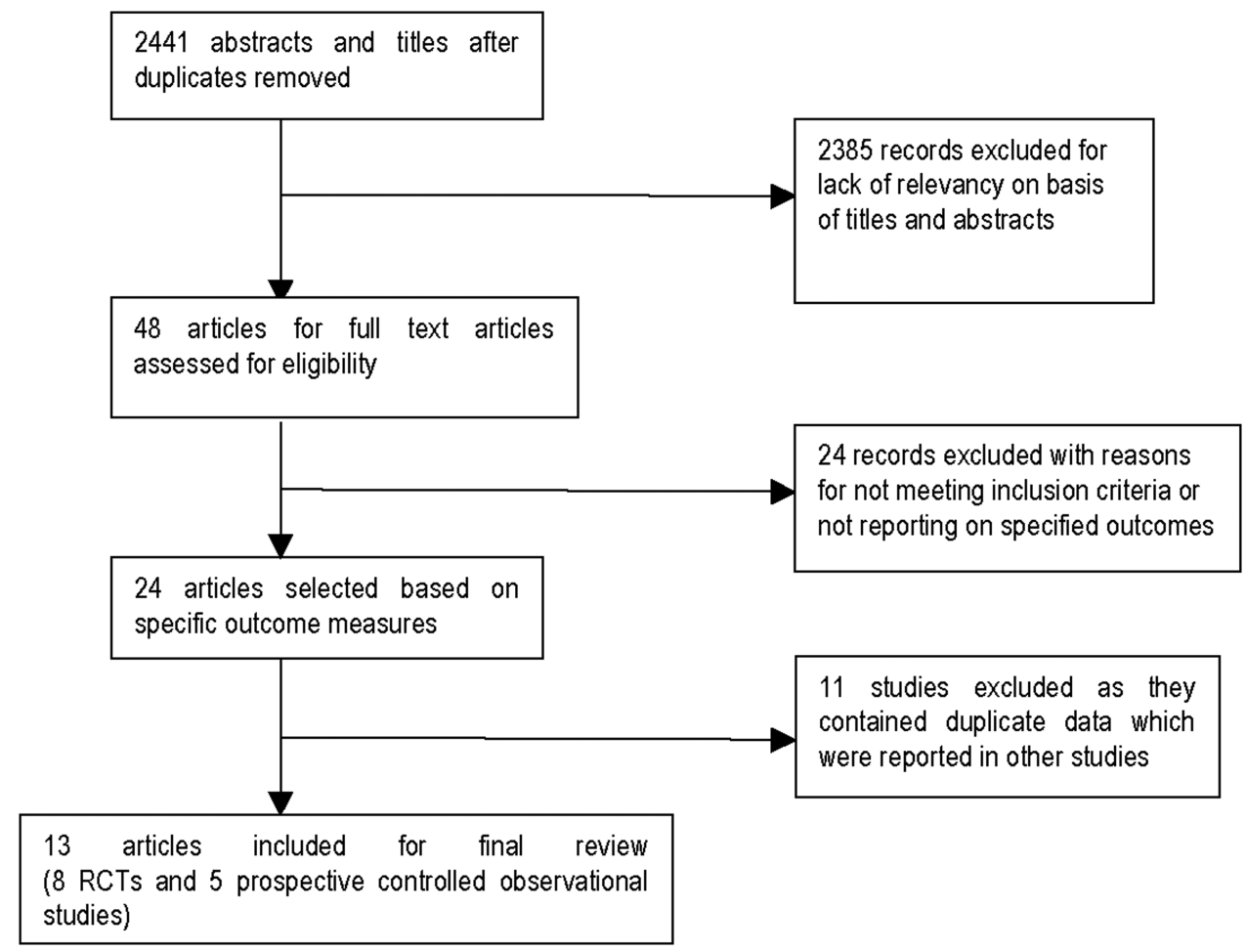

Figure 1 Selection of studies for inclusion in the review (RCT, randomised controlled trial).

\section{Risk of bias}

All RCTs reported adequate randomisation. No study, however, provided explicit statements about allocation concealment. The risk due to blinding study participants was unclear across studies likewise was the risk due to incomplete outcome data. We particularly do not think the attrition rate across studies was significant to introduce a risk of bias in our analysis (table 1).

The five observational studies showed moderately representative cohorts, comparability between cohorts and adequacy of selected outcomes (see table 4).

\section{Uptake of HIV testing}

All randomised trials compared rapid VCT with conventional testing and reported uptake of HIV testing as an individual outcome. We report the findings from Anaya et al separately because this was conducted in a community healthcare facility unlike the other three CB studies. ${ }^{20} 4851$ We excluded one study from the meta-analysis because randomisation was done after the participants had already accepted voluntary HIV testing. ${ }^{50}$

As shown in figure 2A, these studies show a threefold increase in uptake of HIV testing in the rapid VCT arm $(\mathrm{RR}=2.95,95 \%$ CI 1.69 to 5.16). Heterogeneity between the studies was high $\mathrm{I}^{2}=99 \%$. When the results from the Sweat study, a large, tri-country pragmatic CB trial, are considered, there is significant heterogeneity in the site estimates but there is a consistency in the increased likelihood of the participants to accept HIV testing with rapid VCT. ${ }^{20} 57$ The heterogeneity suggests different modes of implementation and varied populations between these countries. This is further highlighted by

Table 1 Risk of bias as assessed using the Cochrane risk of bias tool

\begin{tabular}{|c|c|c|c|c|c|}
\hline Study & $\begin{array}{l}\text { Random } \\
\text { sequence } \\
\text { generation }\end{array}$ & $\begin{array}{l}\text { Allocation } \\
\text { concealment }\end{array}$ & $\begin{array}{l}\text { Blinding of } \\
\text { participants and } \\
\text { personnel } \\
\text { (performance bias) }\end{array}$ & $\begin{array}{l}\text { Blinding of } \\
\text { outcome } \\
\text { assessment } \\
\text { (detection bias) }\end{array}$ & $\begin{array}{l}\text { Incomplete } \\
\text { outcome date } \\
\text { (attrition bias) }\end{array}$ \\
\hline Anaya et a/99 & Unclear risk & Unclear risk & Low risk & Unclear risk & Low risk \\
\hline Coates et $a^{\beta 9}$ & Low risk & High risk & Low risk & Unclear risk & Low risk \\
\hline Lugada et $a^{51}$ & Low risk & Unclear risk & Low risk & Unclear risk & Low risk \\
\hline Malonza et $a^{50}$ & Low risk & Unclear risk & Low risk & Unclear risk & Low risk \\
\hline Read et $a^{58}$ & Low risk & High risk & High risk & Unclear risk & Low risk \\
\hline Spielberg et $a^{52}$ & Low risk & High risk & Low risk & Unclear risk & Low risk \\
\hline Sweat et $a^{20}$ & Low risk & High risk & Low risk & Unclear risk & Low risk \\
\hline Walensky et al ${ }^{48}$ & Low risk & Unclear risk & Low risk & Unclear risk & Low risk \\
\hline
\end{tabular}


Table 2 Characteristics of included studies-randomised controlled trials

\begin{tabular}{|c|c|c|c|c|c|c|c|}
\hline Study & Study method & Participants & Country & Intervention arm & Control arm & $\begin{array}{l}\text { Target } \\
\text { period (if } \\
\text { applicable) }\end{array}$ & Outcome measures \\
\hline Anaya et $a f^{49}$ & $\begin{array}{l}\text { Randomised } \\
\text { controlled trail }\end{array}$ & $\begin{array}{l}\text { Age: } 18-65 \text { years } \\
\text { Sex: male and female } \\
\text { Setting: adult clinic } \\
\text { waiting room patients } \\
\text { within the Department of } \\
\text { Veteran Affairs }\end{array}$ & USA & $\begin{array}{l}\text { 1. Nurse initiated } \\
\text { streamlined VCT with } \\
\text { rapid testing: } 84 \\
\text { participants } \\
\text { 2. Nurse initiated } \\
\text { traditional VCT: } \\
84 \text { participants }\end{array}$ & $\begin{array}{l}\text { Conventional VCT: } \\
83 \text { participants }\end{array}$ & & Testing rates \\
\hline Coates et $a^{5960}$ & $\begin{array}{l}\text { Cluster } \\
\text { randomised } \\
\text { controlled trial }\end{array}$ & $\begin{array}{l}\text { Age: } 16-32 \text { years } \\
\text { Sex: male and female } \\
\text { Setting: area of HIV } \\
\text { prevalence }>1 \%\end{array}$ & $\begin{array}{l}\text { Tanzania, } \\
\text { Zimbabwe, } \\
\text { Thailand, and } \\
\text { South Africa }\end{array}$ & $\begin{array}{l}\text { Community-based rapid } \\
\text { VCT: } 63000 \text { participants }\end{array}$ & $\begin{array}{l}\text { Conventional VCT: } \\
52900 \text { participants }\end{array}$ & 36 months & HIV incidence \\
\hline Lugada et $a^{51}$ & $\begin{array}{l}\text { Cluster } \\
\text { randomised } \\
\text { controlled trial }\end{array}$ & $\begin{array}{l}\text { Age: } 15-49 \text { years } \\
\text { Sex: male and female } \\
\text { Setting: five SE districts } \\
\text { in Uganda* HIV } \\
\text { prevalence: } 5.6 \%\end{array}$ & Uganda & $\begin{array}{l}\text { Home-based rapid VCT } \\
\text { with ART programme: } \\
4798 \text { participants }\end{array}$ & $\begin{array}{l}\text { Conventional } \\
\text { clinic-based ART } \\
\text { programme: } 2386 \\
\text { participants }\end{array}$ & 2 years & $\begin{array}{l}\text { Uptake of testing; } \\
\text { HIV prevalence }\end{array}$ \\
\hline Malonza et $a P^{50}$ & $\begin{array}{l}\text { Randomised } \\
\text { controlled trail }\end{array}$ & $\begin{array}{l}\text { Age: } 18-44 \text { years } \\
\text { Sex: female } \\
\text { Setting: antenatal clinic } \\
\text { attendees } \\
\text { HIV prevalence: } \\
15-35 \%\end{array}$ & Kenya & $\begin{array}{l}\text { Rapid VCT in health } \\
\text { facility: } 627 \text { participants }\end{array}$ & $\begin{array}{l}\text { Conventional HIV } \\
\text { testing (ELISA) } \\
\text { test: } 622 \\
\text { participants }\end{array}$ & 1 year & $\begin{array}{l}\text { Wait period for tests; } \\
\text { receipt of test results; } \\
\text { uptake into } \\
\text { antiretroviral } \\
\text { treatment } \\
\text { programmes }\end{array}$ \\
\hline Read et $a{ }^{58}$ & $\begin{array}{l}\text { Randomised } \\
\text { controlled trial }\end{array}$ & $\begin{array}{l}\text { Age: } \\
\text { Sex: male } \\
\text { Setting: sexual health } \\
\text { service }\end{array}$ & Australia & $\begin{array}{l}\text { Rapid VCT } \\
200 \text { participants }\end{array}$ & $\begin{array}{l}\text { Conventional VCT } \\
200 \text { participants }\end{array}$ & 18 months & $\begin{array}{l}\text { Incidence of HIV } \\
\text { testing, including } \\
\text { testing outside study } \\
\text { clinic }\end{array}$ \\
\hline Spielberg et $a^{\Gamma^{2}}$ & $\begin{array}{l}\text { Cluster } \\
\text { randomised trial }\end{array}$ & $\begin{array}{l}\text { Age: } 14 \text { years and older } \\
\text { Sex: male and female } \\
\text { Setting: needle } \\
\text { exchange and } \\
\text { bathhouse }\end{array}$ & USA & $\begin{array}{l}\text { 1. Rapid testing with } \\
\text { standard counselling: } \\
3965 \\
\text { 2. Oral fluid testing with } \\
\text { standard counselling: } \\
4185\end{array}$ & $\begin{array}{l}\text { 1. Traditional } \\
\text { testing with } \\
\text { standard } \\
\text { counselling: } \\
4364 \\
\text { 2. Traditional } \\
\text { testing with } \\
\text { option of } \\
\text { counselling: } \\
4496\end{array}$ & 221 days & $\begin{array}{l}\text { Uptake of HIV } \\
\text { testing; receipt of test } \\
\text { results }\end{array}$ \\
\hline Sweat et aPO 57 & & $\begin{array}{l}\text { Age: } 16-32 \text { years } \\
\text { Sex: male and female }\end{array}$ & & $\begin{array}{l}\text { Community-based rapid } \\
\text { VCT: } 28240 \text { participants }\end{array}$ & $\begin{array}{l}\text { Conventional VCT: } \\
28916 \text { participants }\end{array}$ & 3 years & \\
\hline
\end{tabular}

Sex: male and female 


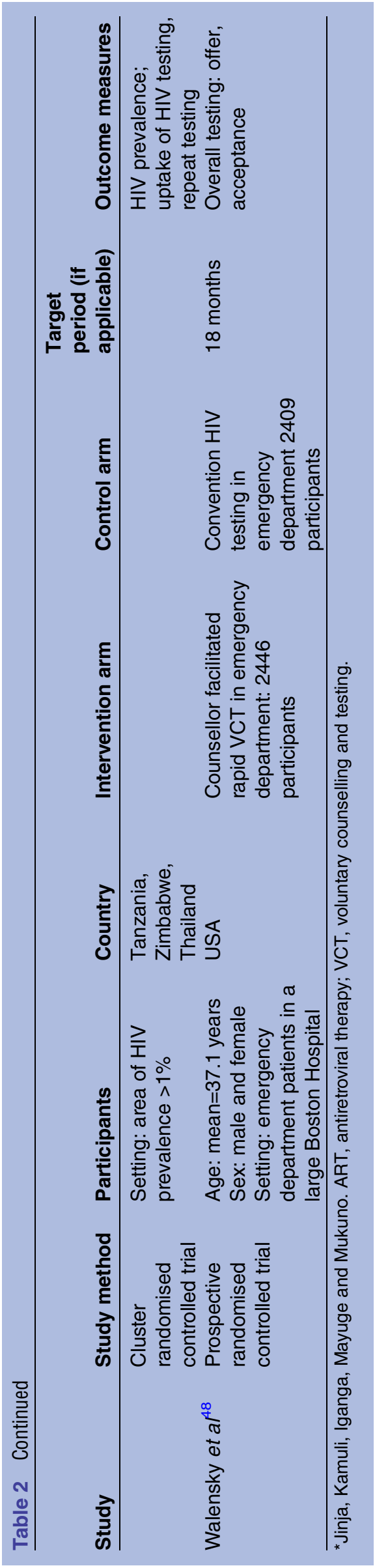

the failure to measure some outcomes such as repeat testing rates in Thailand. The HIV-testing programmes were not limited to specific participants and there was a higher degree of contamination within geographically accessible cluster sites.

Results from two observational studies also showed that participants were more likely to get tested for HIV using a rapid approach. ${ }^{54}$

\section{Receipt of HIV test results}

Results for the receipt of HIV tests from three randomised trials reporting this outcome showed an almost twofold increased likelihood among participants randomised to the rapid approach study arms to receive test results $(\mathrm{RR}=2.14,95 \%$ CI 1.08 to 4.24$)$. Heterogeneity between the studies was high $\left(\mathrm{I}^{2}=93 \%\right.$; $\mathrm{p}=<0.0001$; figure 2$) .{ }^{49} 50$

These estimates were supported by evidence from one of the observational studies conducted among bathhouse patrons in a large US city with a significant proportion being men who had sex with men. ${ }^{55}$ The results showed a significant difference in the proportion of men who received results of HIV tests: among HIV-positive men there was a $34.6 \%$ risk difference, and among HIV-negative men a $26 \%$ risk difference, when rapid VCT was compared with conventional testing.

\section{Repeat HIV testing and test incidence rate}

The international cluster $\mathrm{RCT}^{20}$ sought to indirectly measure personal awareness, entry of participants into a HIV care and treatment programme, and maturation of prevention initiatives. This study included three countries: Tanzania, Zimbabwe and Thailand that recruited 10,8 and 14 community clusters, respectively. Because each country reported data separately, and because there appeared to be differences in methods, we treated each country as a separate study in this meta-analysis. Thailand was not included in our repeat testing meta-analysis because data was not available for this outcome. The analysis showed an $\mathrm{RR}=2.28,95 \%$ CI 0.35 to 15.07 suggesting increased HIV repeat testing among those in the intervention $\operatorname{arm}(\mathrm{RR}=2.28,95 \%$ CI 0.35 to 15.07 ; figure 3$) .{ }^{20}$ Sweat $e t$ al also reported a consistent increase in repeat HIV testing in Thailand and Zimbabwe reaching 28\% of all testing done in the CB VCT sites.

The Australia RCT of men known to the public sexual health service reported a test incidence rate ratio 1.15 , 95\% CI 0.96 to $1.38 .^{58}$ Men randomised to the conventional testing reported the wait for the test result was too long $(\mathrm{p}<0.001)$ and reported anxiety because of the wait $(p<0.002)$ while men in the rapid VCT reported convenience in obtaining results $(\mathrm{p}<0.001)$. Other RCTs did not report on repeat testing preferences.

\section{HIV incidence}

HIV incidence data by Coates $e t a e^{596}$ over a 36-month period in five countries showed an $11 \%$ reduction in estimated incidence in intervention vs control communities $(\mathrm{RR}=0.89,95 \% \mathrm{CI}=0.63$ to 1.24 ; see figure 4$)$. 
Table 3 GRADE evidence profile and summary of findings for use of rapid approaches for improving health outcomes

\begin{tabular}{|c|c|c|c|c|c|c|}
\hline Outcomes & $\begin{array}{l}\text { Effects of rapid testing } \\
\text { approaches on HIV } \\
\text { outcomes }\end{array}$ & $\begin{array}{l}\text { Relative } \\
\text { effect } \\
(95 \% \mathrm{Cl})\end{array}$ & $\begin{array}{l}\text { Anticipated } \\
\text { absolute } \\
\text { effect with } \\
\text { control }\end{array}$ & $\begin{array}{l}\text { Risk } \\
\text { difference } \\
\text { with } \\
\text { intervention }\end{array}$ & $\begin{array}{l}\text { Number of } \\
\text { participants } \\
\text { (studies) }\end{array}$ & $\begin{array}{l}\text { Quality of } \\
\text { the } \\
\text { evidence } \\
\text { (GRADE) }\end{array}$ \\
\hline $\begin{array}{l}\text { Uptake of } \\
\text { testing } \\
\text { Follow-up: } \\
\text { 12-36 months }\end{array}$ & $\begin{array}{l}\text { Three RCTs included in the } \\
\text { analysis provided consistent } \\
\text { point estimates showing } \\
\text { uptake of testing was } \\
\text { significantly better among } \\
\text { participants randomised to } \\
\text { rapid testing approaches }\end{array}$ & $\begin{array}{l}R R=2.95 \\
(1.69 \text { to } \\
5.16)\end{array}$ & $\begin{array}{l}145 \text { more per } \\
1000\end{array}$ & $\begin{array}{l}282 \text { cases } \\
\text { more per } 1000 \\
(100-602)\end{array}$ & $\begin{array}{l}80400 \\
\text { (4 studies) } \\
18350^{*}\end{array}$ & $\begin{array}{l}\oplus \oplus \oplus \ominus \\
\text { Moderate† }\end{array}$ \\
\hline $\begin{array}{l}\text { Receipt of } \\
\text { results } \\
\text { Follow-up: } \\
\text { 12-24 months }\end{array}$ & $\begin{array}{l}\text { Two RCTs reported rapid } \\
\text { approaches resulted in higher } \\
\text { receipt of HIV test results. } \\
\text { However due to the } \\
\text { heterogeneity-variations in } \\
\text { population characteristics, the } \\
\text { pooled estimates were not } \\
\text { statistically significant }\end{array}$ & $\begin{array}{l}R R=2.14 \\
(1.04 \text { to } \\
4.24)\end{array}$ & $\begin{array}{l}213 \text { more per } \\
1000\end{array}$ & $\begin{array}{l}243 \text { cases per } \\
1000(17-691)\end{array}$ & $\begin{array}{l}18426 \\
\text { (3 studies) } \\
4680^{*}\end{array}$ & $\begin{array}{l}\oplus \oplus \oplus \ominus \\
\text { Moderate† }\end{array}$ \\
\hline $\begin{array}{l}\text { Combined } \\
\text { effect of } \\
\text { repeat testing } \\
\text { Follow-up: } \\
36 \text { months }\end{array}$ & $\begin{array}{l}\text { One large Cluster RCT found } \\
\text { a very large effect for this } \\
\text { outcome with participants } \\
\text { randomised to rapid testing } \\
\text { approaches twice more likely } \\
\text { to have repeat HIV tests }\end{array}$ & $\begin{array}{l}R R=2.28 \\
(0.35 \text { to } \\
15.07)\end{array}$ & $\begin{array}{l}97 \text { more per } \\
1000\end{array}$ & $\begin{array}{l}124 \text { cases per } \\
1000(63 \\
\text { fewer }-1000 \\
\text { more) }\end{array}$ & $\begin{array}{l}10706 \\
\text { (1 study) }\end{array}$ & $\begin{array}{l}\oplus \oplus \oplus \Theta \\
\text { Moderate } \dagger\end{array}$ \\
\hline $\begin{array}{l}\text { HIV incidence } \\
\text { Follow-up: } \\
36 \text { months }\end{array}$ & $\begin{array}{l}\text { HIV incidence did decrease in } \\
\text { intervention clusters } \\
\text { compared with control } \\
\text { clusters, but this effect was } \\
\text { not statistically significant }\end{array}$ & $\begin{array}{l}R R=0.89 \\
(0.63 \text { to } \\
1.24)\end{array}$ & $\begin{array}{l}81 \text { more per } \\
1000\end{array}$ & $\begin{array}{l}9 \text { cases per } \\
1000(30 \\
\text { fewer-19 } \\
\text { more })\end{array}$ & $\begin{array}{l}115300 \\
7189^{*} \\
\text { (1 study) }\end{array}$ & $\begin{array}{l}\oplus \oplus \Theta \\
\text { Low‡' § }\end{array}$ \\
\hline \multicolumn{7}{|c|}{$\begin{array}{l}\text { GRADE Working Group grades of evidence. } \\
\text { High quality. Further research is very unlikely to change our confidence in the estimate of effect. } \\
\text { Moderate quality. Further research is likely to have an important impact on our confidence in the estimate of effect and may change the } \\
\text { estimate. } \\
\text { Low quality. Further research is very likely to have an important impact on our confidence in the estimate of effect and is likely to change the } \\
\text { estimate. } \\
\text { Very low quality. We are very uncertain about the estimate. } \\
\text { *Adjusted sample size after applying the intracluster correlation coefficient. } \\
\text { †Outcome of HIV incidence was downgraded because allocation concealment was unclear, blinding of intervention not possible and inability } \\
\text { to determine blinding of researchers. } \\
\text { †Outcome of HIV incidence was downgraded because allocation concealment was unclear, blinding of intervention not possible and inability } \\
\text { to determine blinding of researchers and imprecision of estimates. } \\
\text { §Number of participants included in the analysis is not available from the abstracts. } \\
\text { RCT, randomised controlled trial; RR, relative risk. }\end{array}$} \\
\hline
\end{tabular}

\section{Treatment programme uptake}

Malonza et $a \tilde{l}^{0}$ reported that all of the women in the study were offered free antiretroviral drugs irrespective of study arm and the study found OR=1.7, 95\% CI 0.8 to 3.7 for the uptake of perinatal HIV-1 interventions between rapid VCT versus conventional VCT.

\section{HIV-related stigma}

HIV-related stigma was assessed only in Project Accept and showed that stigma was low at baseline with little room for further decrease. ${ }^{59}$

\section{Heterogeneity and sensitivity analysis}

Our analysis included studies conducted in a range of countries, contexts, settings and populations. The studies also involved different variants of rapid VCT.
Heterogeneity was statistically significant for all outcomes with more than one study.

Age: Sweat et al reported a reduction in HIV incidence of $1.5 \%$ among 18-24-year-olds and a $25 \%$ reduction in HIV incidence among participants aged 25-32 years $(\mathrm{RR}=0.75 ; 95 \%$ CI 0.54 to $1.04, \mathrm{p}=0.08) .{ }^{60}$ In Uganda, Lugada et $a \tilde{l}^{1}$ reports that persons aged $15-24$ years were least likely to get tested.

Sex/gender: We were only able to report subgroup analysis on gender in one trial because data was not disaggregated in the other studies. ${ }^{20} 57$ The Sweat study reported a greater reduction in HIV incidence in men than women in the intervention arm. An $11.6 \%$ reduction in HIV incidence among women was reported $(\mathrm{RR}=0.89 ; 95 \%$ CI 0.73 to $1.07, \mathrm{p}=0.17)$ and $19.3 \%$ in men $\quad(\mathrm{RR}=0.81 ; 95 \%$ CI 0.57 to $1.15, \mathrm{p}=0.19)$. In 
Table 4 Newcastle-Ottawa Quality Assessment ScaleObservational Study Star Template

\begin{tabular}{|c|c|c|c|}
\hline Study & Selection & Comparability & exposure \\
\hline Appiah et $a^{56}$ & 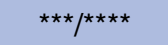 & $\star / \star \star$ & 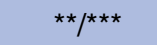 \\
\hline uebner et $a^{55}$ & 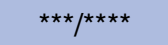 & $\star / \star \star$ & 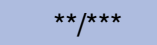 \\
\hline et $a p^{54}$ & $\star \star \star \star / * * \star \star *$ & $* / * *$ & 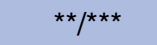 \\
\hline et $a^{29}$ & $\star \star * * / * \star \star *$ & $\star / * \star$ & $\star * / * \star *$ \\
\hline White et $a^{53}$ & 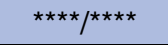 & $* / * *$ & 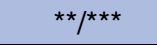 \\
\hline \multicolumn{4}{|c|}{$\begin{array}{l}\text { Selection-maximum of } 4 \text { stars (representativeness of exposed } \\
\text { cohort; selection of non-exposed cohort; and exposure). } \\
\text { Comparability-maximum of } 2 \text { stars (comparability between } \\
\text { cohorts). } \\
\text { Outcome/ Exposure-maximum of } 3 \text { stars (adequacy of outcome, } \\
\text { follow-up duration). } \\
\text { Adapted from Wells et al. }{ }^{47} \text { Available at http://www. } \\
\text { evidencebasedpublichealth.de. }\end{array}$} \\
\hline
\end{tabular}

addition, women older than 24 years in the intervention arm had a $30.2 \%$ reduction in HIV incidence versus conventional testing $(95 \%$ CI 0.54 to 0.90 , $\mathrm{p}=0.009) .^{20} 5760$

In another RCT, females were significantly more likely to accept HIV testing than men, adjusted OR (1.18, 95\% CI 1.07 to 1.30$)^{51}$

Education: Subgroup analyses by Lugada et a $\tilde{e}^{1}$ and Malonza et $a \tilde{l}^{\tilde{0}}$ also showed that irrespective of level of education, participants were more likely to accept HIV testing if it employed a rapid VCT.

\section{Applicability and quality of evidence}

This review aimed to be relevant for people at high risk for exposure to HIV. The GRADE summary of findings table with patient important outcome and certainty estimates can be found in table $3{ }^{44}{ }^{61-63}$ The evidence for uptake of HIV testing, receipt of results and repeat testing were considered moderate quality because of randomisation and allocation concerns. The evidence for HIV incidence is considered low quality due to concerns of risk of bias and the imprecision of the estimates. We did not downgrade for indirectness because the included studies were conducted in community and health facility settings making the estimates applicable across a wide range of settings.

\section{DISCUSSION}

While HIV awareness is improving, many communities and individuals still face barriers to HIV testing and viral load suppression. Our systematic review studied a complex intervention with three critical components designed to improve voluntary counselling and uptake of testing (engagement), reduce travel and improve receipt of test results (convenience), and to facilitate provision of results with appropriate information on treatment and counselling (long-term intervention). Rapid VCT was studied in health facility and CB interventions and in diverse settings where there is a high risk for HIV exposure; such as bathhouses, STD clinics, inner city ED, tuberculosis (TB) programmes and antenatal programmes in endemic regions. Rapid VCT showed large increase in update of testing and receipt of test results. Observational studies have also shown that VCT is associated with a reduction in the HIV disease burden. ${ }^{39}$

In the studies analysed, no harms were identified despite hypothetical concerns of test inaccuracy, lack of privacy and abuse to healthcare workers in non-hospital environments. A recent systematic review of observational studies focusing on home-based rapid VCT also failed to identify harms. ${ }^{27}$

Until recently, some organisations have argued that HIV testing should continue using the conventional clinic or hospital testing approach. ${ }^{11}$ This is changing and our findings clearly suggest high-risk populations benefit from rapid VCT compared with conventional testing, especially in terms of uptake and receipt of results. ${ }^{35}$ CB VCT, which also uses a facilitated rapid approach with community engagement, has received considerable WHO and research attention. ${ }^{39} 65$ Our systematic review corroborates these and other CB findings. ${ }^{26}$

Our review however specifically focused on populations at high risk of exposure to HIV, with the hypothesis that use of rapid VCT will increase HIV testing and receipt of testing rates and increase access to HIV-related treatment and services. Evidence from our study showed consistency of effect across settings, evidence for improved uptake in men, no uptake difference with low education status. These findings were corroborated by the evidence from prospective observational studies. ${ }^{54} 55$ Sweat et $a l^{20}$ and Coates et a $t^{60}$ reported $\mathrm{CB}$ rapid VCT was associated with improved behaviour change and prevention. The results from our study are applicable across a variety of settings; for example, among at-risk youth, women and hard to reach men in Zimbabwe and Thailand, repeat testing rates were comparable with those found in facilitated testing in high-risk men who have sex with men population in the USA. ${ }^{55}$ Lugada et a $\tilde{l}^{51}$ demonstrated that men used rapid-testing approaches but that this usage was slightly less than women. This is an important finding because men are usually harder to reach for HIV testing and treatment programmes. ${ }^{1466}$ The findings of our review are also similar to a recent meta-analysis that shows increased receipt of HIV testing with rapid HIV VCT in medical facilitities. ${ }^{67}$

Rapid VCT has emerged as a complex intervention that can be used in community settings and health facilities in low-income and high-income countries. Previous systematic reviews have not included rapid VCT studies conducted in health facilities, thus leaving rapid VCT approach primarily directed at $\mathrm{CB}$ initiatives; for example, the WHO HIV guidelines highlights CB VCT, but not rapid VCT for health facilities.

Finally, our study highlights the importance of three key components within a counselling and testing 


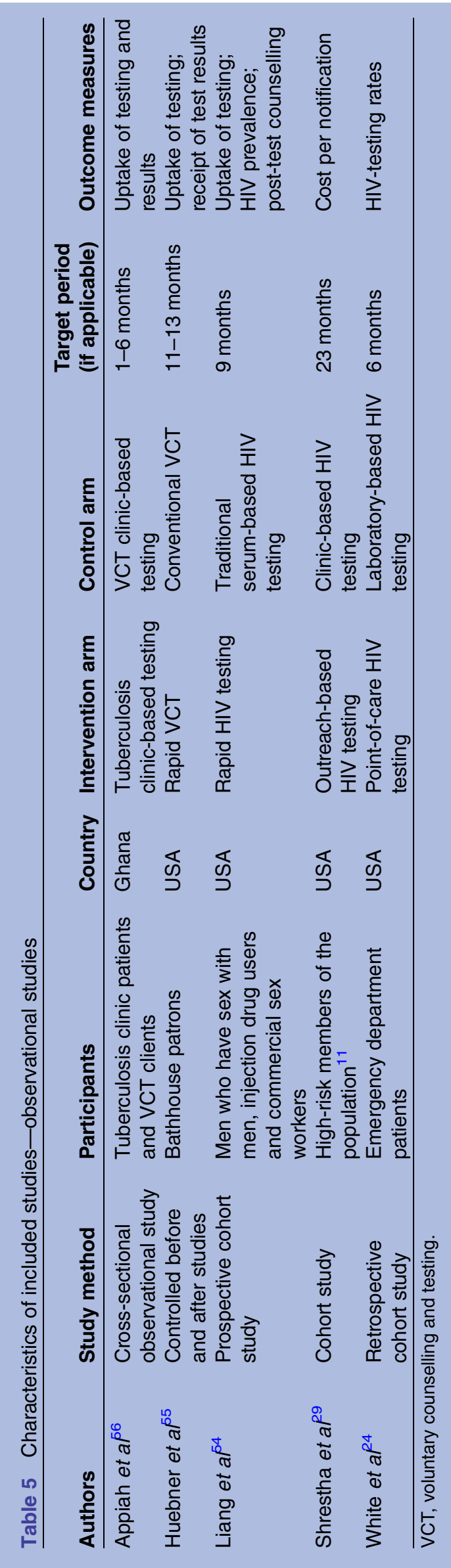

strategy. Complex interventions include components with varying degrees of interaction. ${ }^{68}$ We suggest ongoing research is needed to improve HIV testing and viral load suppression: and this should include recognition of interacting components within the intervention, the number and difficulty of behaviours required by those delivering or receiving the intervention, the number of organisational levels targeted by the intervention, the number and variability of outcomes, and the degree of flexibility or tailoring of the intervention. ${ }^{69}$ Understanding this variability is also important for economic analysis.

\section{IMPLICATION FOR POLICY AND PRACTICE}

Our study has shown the benefit of rapid VCT on uptake of HIV testing and receipt of results. ${ }^{70}$ This testing approach was effective in health facilities as well as community settings. CB VCT has received explicit attention in the recent WHO HIV testing and treatment guidelines and WHO consolidated guidelines for key populations. ${ }^{39} 42$ Our work supports CB VCT, but also finds that persons at high risk of exposure to HIV who use health facilities benefit from rapid VCT. This finding is not yet reflected in the WHO Consolidated Guidelines for key populations. ${ }^{42}$ We also found some emerging evidence for increased HIV awareness in most care settings. $^{71}$

Implementing rapid VCT, with testing components tailored for high-risk communities, could improve health equity through earlier HIV diagnosis with possible retention in viral suppression programmes, reduced transmission and longer lifespans. ${ }^{7-9}$ In high-income countries, our results have particular importance for Aboriginal population, persons who inject drugs, prison populations, and certain migrant and minority populations. Additionally, routine use of rapid VCT may avoid human rights violations among marginalised populations where testing may occur without informed consent and were existing stigma may create barriers to testing and treatment. Given the significant heterogeneity in the trials, we suggest more research to study the components of the rapid VCT and identify what works, for whom and in what settings.

\section{STRENGTHS AND LIMITATIONS}

We used a rigorous and transparent systematic review method, with an a priori protocol. The equity-focus allowed us to explicitly report how we assessed effects in populations at high risk of exposure to HIV; for example, by using explicit data collection methods to assess robustness of effect across SES, sex and level of education. ${ }^{40}$ In addition, our analysis included studies from various geographical areas covering four continents (Africa, Asia, Australia and North America) and diverse high-risk populations and testing settings (community and hospital), unlike previous reviews. ${ }^{26}$ Three of eight studies in our analysis were cluster RCTs, a 

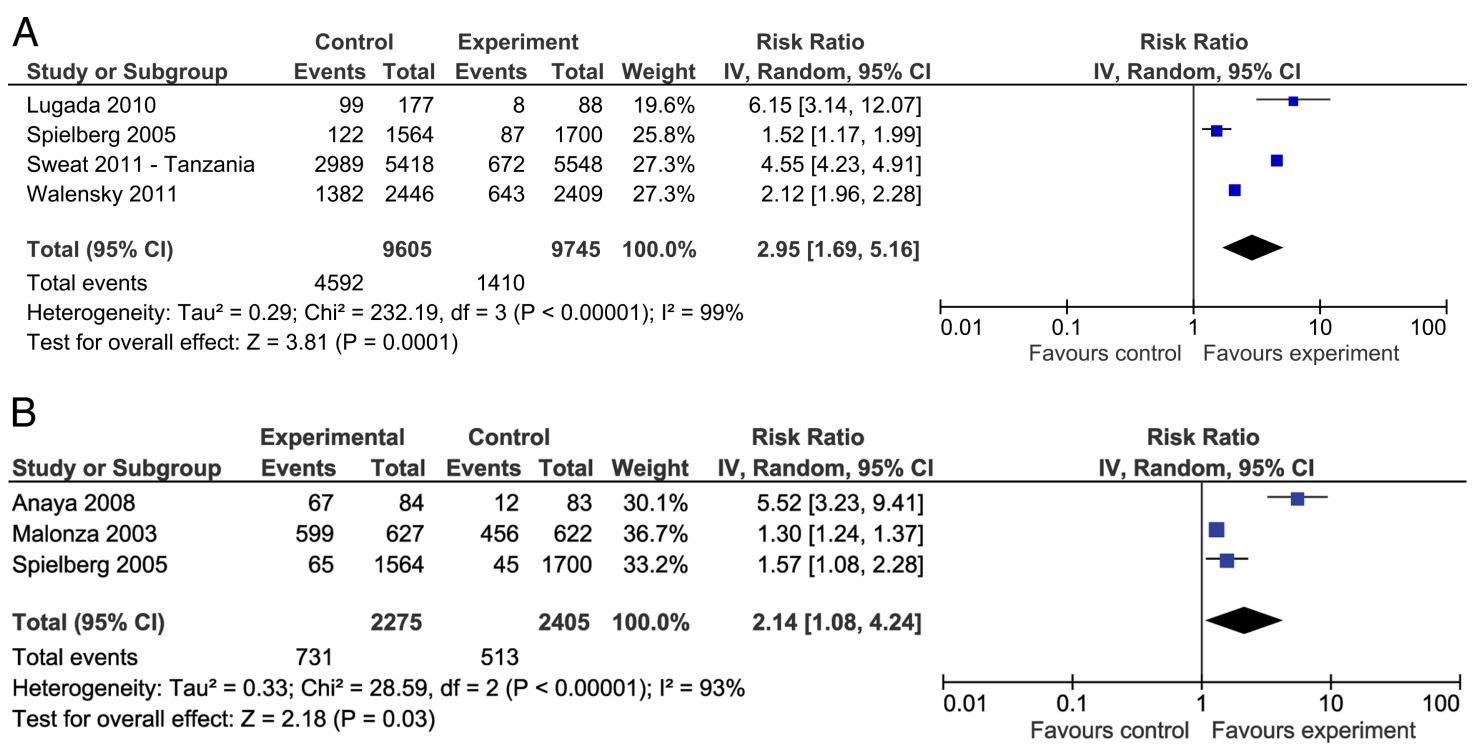

Figure 2 Forest plot of rapid HIV voluntary counselling and testing versus conventional care (A) on uptake of HIV testing and (B) on receipt of HIV results

design that is good for evaluating health service and CB interventions where the intervention is delivered at a group level. $^{20} 5172$

Despite the strengths of our analysis, there are a number of limitations. First, the components of the rapid VCT intervention varied across studies yet our data did not allow for quantitative comparisons of the components. Second, the studies were conducted in a variety of community and health facility settings and these settings also contributed to variations in implementation and convention testing. Third, while our analysis included studies from four continents, there were no studies from Europe and only eight RCTs in total. Fourth, we identified limited allocation concealment in the CB studies as well as healthcare facility-based studies. Finally, the studies that were included did not report on the impact on HIV-related stigma.

\section{CONCLUSION}

There still exist a significant proportion of HIV-infected people who are unaware of their status, lack access to HIV services such as VCT and are at risk of transmitting the virus within their communities. Our review focused on people at high risk of exposure to HIV to study the effect of rapid VCT compared with conventional testing. We studied a complex intervention with three critical components to improve initial counselling and update, optimise receipt of results and to facilitate trust in provision of results, counselling and treatment. Rapid VCT showed large increases in update of testing and in receipt of test results. Results were applicable to health facilities or $\mathrm{CB}$ interventions and in diverse settings such as bathhouses, prisons, home-based testing, ED, antenatal programmes, TB programmes and primary care clinics. No significant harms were identified in this testing approach. Evidence from our studies showed consistency of effect, evidence for favourable uptake in men in Africa and an $11 \%$ decrease in HIV incidence after 3 years of $\mathrm{CB}$ testing; however, precision of this estimate was low. These findings contribute new evidence for HIV-testing components that are relevant for HIV guidelines, supporting CB rapid VCT and highlighting a role for more health facility-based rapid VCT for populations at high risk of exposure. More research is needed to examine the relative effectiveness of the three components within rapid VCT and to study the association of rapid VCT and uptake of HIV treatment and long-term viral suppression.

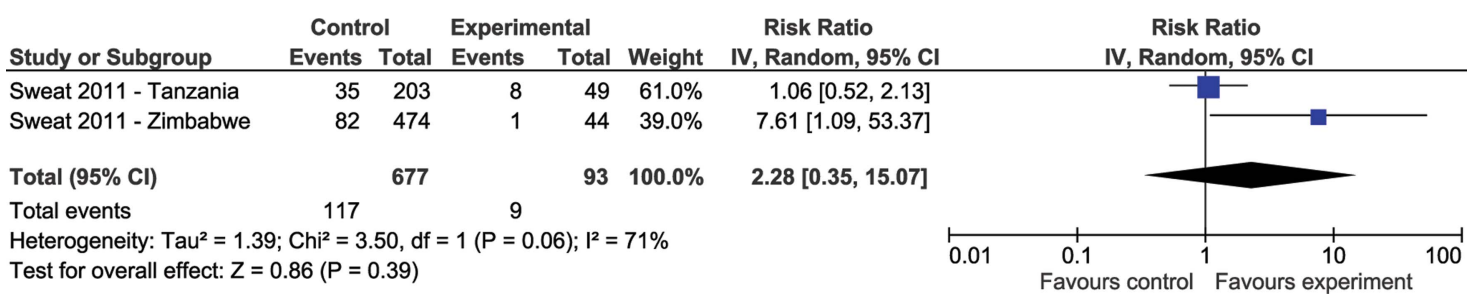

Figure 3 Forest plot of effect of rapid voluntary counselling and testing testing approaches versus conventional care on repeat testing. 


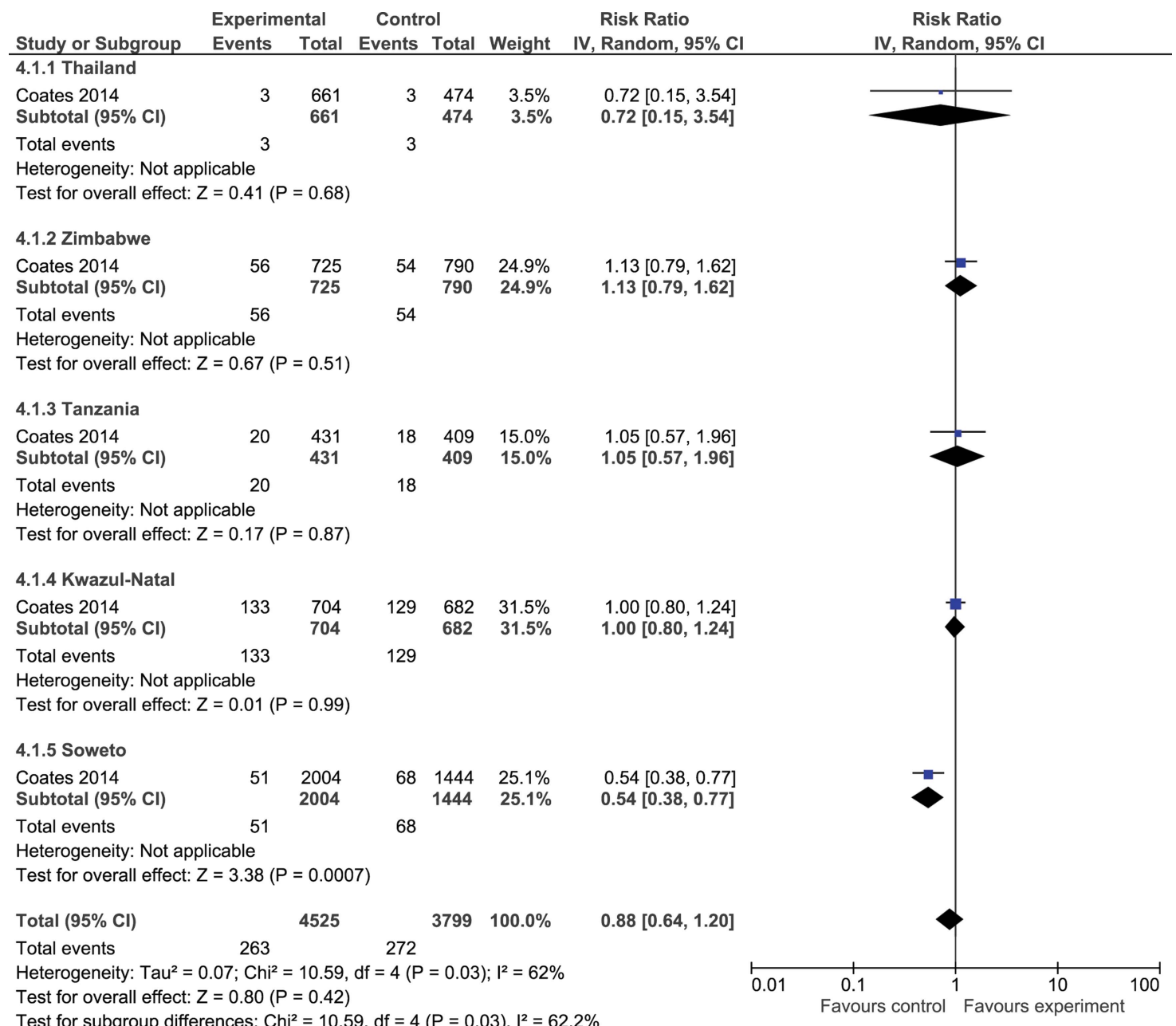

Figure 4 Forest plot of effect of rapid voluntary counselling and testing versus convention testing on HIV incidence.

\section{Author affiliations}

${ }^{1}$ Department of Family Medicine, University of Ottawa, Ottawa, Ontario, Canada

${ }^{2}$ Centre for Global Health, Institute of Population Health, University of Ottawa, Ottawa, Ontario, Canada

${ }^{3}$ Department of Epidemiology and Community Medicine, University of Ottawa, Ottawa, Ontario, Canada

${ }^{4}$ Bruyere Research Institute, Bruyere Continuing Care

${ }^{5}$ Ottawa Hospital Research Institute, The Ottawa Hospital

${ }^{6}$ Division of Infectious Disease, Department of Medicine, University of Ottawa, Ottawa, Ontario, Canada

${ }^{7}$ University of Ottawa Heart Institute, University of Ottawa, Ottawa, Ontario,

Canada

${ }^{8}$ Canada Foundation for Nepal, Ottawa, Ontario, Canada

Acknowledgements The authors would like to acknowledge the Canadian Institutes of Health Research for funding this systematic review and synthesis. They would also like to acknowledge Joy Oliver of the Cochrane Collaboration HIV Review Group for her expert librarian services and Kamila Premji for her helpful comments on an earlier version of this manuscript.

Contributors KP conceived the study and received funding with VW, TR. $\mathrm{KP}$ and VW were involved in the development and oversight of the statistical analysis plan and in the writing of the review. OM analysed the data and prepared the initial draft and revised the paper. GPD designed the data extraction tool, reviewed the studies for inclusion in the analysis and review of the draft. MT provided clinical HIV expertise and revised the draft paper. TR developed the search strategy used for identifying the relevant studies.
GW reviewed and provided additional expertise for the complex intervention and statistical analysis plan. All authors approved the final version.

Funding This research received no specific grant from any funding agency in the public, commercial or not-for-profit sectors.

Competing interests None.

Provenance and peer review Not commissioned; externally peer reviewed.

Data sharing statement No additional data are available.

Open Access This is an Open Access article distributed in accordance with the Creative Commons Attribution Non Commercial (CC BY-NC 4.0) license, which permits others to distribute, remix, adapt, build upon this work noncommercially, and license their derivative works on different terms, provided the original work is properly cited and the use is non-commercial. See: http:// creativecommons.org/licenses/by-nc/4.0/

\section{REFERENCES}

1. Joint United Nations Panel on HIV/AIDS (UNAIDS) Global ReportUNAIDS report on the global AIDS epidemic 2012. Geneva, 2012.

2. Joint United Nations Panel on HIVIAIDS (UNAIDS) - UNAIDS Terminology Guidelines-revised version. Geneva, 2011.

3. Joint United Nations Panel on HIV/AIDS (UNAIDS). AIDS epidemic update. Geneva, 2007.

4. Miro JM, Manzardo C, Mussini C, et al. Survival outcomes and effect of early vs. deferred cART among HIV-infected patients diagnosed at the time of an AIDS-defining event: a cohort analysis. PLOS ONE 2011;6:e26009.

5. Siegfried N, Uthman OA, Rutherford GW. Optimal time for initiation of antiretroviral therapy in asymptomatic HIV-infected 
treatment-naive adults (review). Cochrane Database Syst Rev 2010; (3):CD008272.

6. Mulissa Z, Jerene D, Lindtjørn B. Patients present earlier and survival has improved, but pre-ART attrition is high in a six-year HIV cohort data from Ethiopia. PLOS ONE 2010;5:e13268.

7. Gianella S, von Wyl V, Fischer M, et al. Effect of early antiretroviral therapy during primary HIV-1 infection on cell-associated HIV-1 DNA and plasma HIV-1 RNA. Antivir Ther 2011;16:535-45.

8. Cohen MS, Chen YQ, McCauley M, et al. Prevention of HIV-1 infection with early antiretroviral therapy. $N$ Engl J Med 2011;365:493-505

9. Bärnighausen T, Salomon JA, Sangrujee N. HIV treatment as prevention: issues in economic evaluation. PLoS Med 2012;9: e1001263

10. Centers for Disease Control and Prevention (CDC). Vital signs: HIV infection, testing, and risk behaviors among youths-United States. Morb Mortal Wkly Rep 2012;61:971-6.

11. Chou R, Cantor AG, Zakher B, et al. Screening for HIV in pregnant women: systematic review to update the 2005 U.S. Preventive Services Task Force recommendation. Ann Intern Med 2012;157:719-28.

12. Niccolai LM, Verevochkin SV, Toussova OV, et al. Estimates of HIV incidence among drug users in St. Petersburg, Russia: continued growth of a rapidly expanding epidemic. Eur $J$ Public Health 2011;21:613-19.

13. Coovadia HM. Access to voluntary counseling and testing for HIV in developing countries. Ann N Y Acad Sci 2000;918:57-63.

14. World Health Organization (WHO). Global HIV/AIDS responseProgress Report 2011. Geneva.

15. MacArthur GJ, Minozzi S, Martin N, et al. Opiate substitution treatment and HIV transmission in people who inject drugs: systematic review and meta-analysis. BMJ 2012;345:e5945.

16. Wood E, Montaner JSG, Li K, et al. Burden of HIV infection among aboriginal injection drug users in Vancouver, British Columbia. Am J Public Health 2008;98:515-19.

17. Bruneau J, Daniel M, Abrahamowicz M, et al. Trends in human immunodeficiency virus incidence and risk behavior among injection drug users in Montreal, Canada: a 16-year longitudinal study. Am J Epidemiol 2011;173:1049-58.

18. Wiessing L, Likatavicius G, Hedrich D, et al. Trends in HIV and hepatitis $C$ virus infections among injecting drug users in Europe, 2005 to 2010. Euro Surveill 2011:16:1-5.

19. Prentice T. Alarming rates of HIV/AIDS for Canada's Aboriginal women. Can Womens Health Netw 2005;8. http://www.cwhn.ca/ node/39483

20. Sweat M, Morin S, Celentano D, et al. Community-based intervention to increase HIV testing and case detection in people aged 16-32 years in Tanzania, Zimbabwe, and Thailand (NIMH Project Accept, HPTN 043): a randomised study. Lancet Infect Dis 2011:11:525-32.

21. Obermeyer $\mathrm{CM}$, Osborn $\mathrm{M}$. The utilization of testing and counseling for HIV: a review of the social and behavioral evidence. Am J Public Health 2007:97:1762-74.

22. Spielberg F, Kurth A, Gorbach PM, et al. Moving from apprehension to action: HIV counseling and testing preferences in three at-risk populations. AIDS Educ Prev 2001;13:524-40.

23. de la Fuente L, Delgado J, Hoyos J, et al. Increasing early diagnosis of HIV through rapid testing in a street outreach program in Spain. AIDS Patient Care STDs 2009;23:625-9.

24. White DA, Scribner AN, Schulden JD, et al. Results of a rapid HIV screening and diagnostic testing program in an urban emergency department. Ann Emerg Med 2009;54:56-64.

25. Gordon MS, Kinlock TW, Rich JD. Rapid HIV testing for individuals on probation/parole: outcomes of an intervention trial. AIDS Behav 2013;17:2022-30.

26. Bateganya M, Abdulwadud OA, Kiene S. Home-based HIV voluntary counselling and testing (VCT) for improving uptake of HIV testing. Cochrane Database Syst Rev 2010;(7):CD006493.

27. Sabapathy K, Van den Bergh R, Fidler S, et al. Uptake of home-based voluntary HIV testing in sub-Saharan Africa: a systematic review and meta-analysis. PLoS Med 2012;9: e1001351.

28. Plate DK. Evaluation and implementation of rapid HIV tests: the experience in 11 African Countries. AIDS Res Hum Retroviruses 2007:23:1491-8.

29. Shrestha RK, Clark HA, Sansom SL, et al. Cost-effectiveness of finding new HIV diagnoses using rapid HIV testing in community-based organizations. Public Health Rep 2008;123 (Suppl):94-100.

30. Sanders GD, Anaya HD, Asch S, et al. Cost-effectiveness of strategies to improve HIV testing and receipt of results: economic analysis of a randomized controlled trial. J Gen Intern Med 2010;25:556-63.

31. Farnham PG, Hutchinson AB, Sansom SL, et al. Comparing the costs of HIV screening strategies and technologies in health-care settings. Public Health Rep 2008;123(Suppl):51-62.

32. Hutchinson AB, Branson BM, Kim A, et al. A meta-analysis of the effectiveness of alternative HIV counseling and testing methods to increase knowledge of HIV status. AIDS 2006;20:1597-604.

33. King AM, Osterwalder JJ, Vernazza PL. A randomised prospective study to evaluate a rapid HIV-antibody assay in the management of cases of percutaneous exposure amongst health care workers. Swiss Med Wkly 2001;131:10-13.

34. Branson BM, Handsfield HH, Lampe MA, et al. Revised recommendations for HIV testing of adults, adolescents, and pregnant women in health-care settings. MMWR Recomm Rep 2006;55:1-17.

35. McCollum ED, Preidis GA, Maliwichi M, et al. Clinical versus rapid molecular HIV diagnosis in hospitalized African infants: a randomized controlled trial simulating point-of-care infant testing. J Acquir Immune Defic Syndr 2014;66:e23-30.

36. Corbett EL, Makamure B, Cheung YB, et al. HIV incidence during a cluster-randomized trial of two strategies providing voluntary counselling and testing at the workplace, Zimbabwe. AIDS 2007;21:483-9.

37. Hensen B, Baggaley R, Wong VJ, et al. Universal voluntary HIV testing in antenatal care settings: a review of the contribution of provider-initiated testing \& counselling. Trop Med Int Health 2012;17:59-70.

38. Thornton AC, Delpech V, Kall MM, et al. HIV testing in community settings in resource-rich countries: a systematic review of the evidence. HIV Med 2012;13:416-26.

39. World Health Organization. Consolidated guidelines on the use of antiretroviral drugs for treating and preventing HIV infection: recommendations for a public health approach. Geneva, 2013.

40. Welch V, Petticrew M, Tugwell P, et al. PRISMA-Equity 2012 extension: reporting guidelines for systematic reviews with a focus on health equity. PLoS Med 2012;9:e1001333.

41. Pottie K, Dahal G, Logie C, et al. Rapid testing for improving uptake of HIV/AIDS services in people with HIV infection. Cochrane Database Syst Rev 2011;(11):CD003507.

42. World Health Organization (WHO). Consolidated guidelines on HIV prevention, diagnosis, treatment and care for key populations. Geneva, Switzerland: 2014 (in press).

43. Higgins JP, Altman DG, Gøtzsche PC, et al. The Cochrane Collaboration's tool for assessing risk of bias in randomised trials BMJ 2011;343:d5928.

44. Guyatt GH, Oxman AD, Vist G, et al. GRADE guidelines: 4. Rating the quality of evidence-study limitations (risk of bias). J Clin Epidemiol 2011;64:407-15.

45. Higgins JPT, Green S, eds. Cochrane handbook for systematic reviews of interventions 4.2.6. 4th edn. Chichester, UK: The Cochrane Collaboration, 2006.

46. Fylkesnes K, Sandøy IF, Jürgensen M, et al. Strong effects of home-based voluntary HIV counselling and testing on acceptance and equity: a cluster randomised trial in Zambia. Soc Sci Med 2013;86:9-16

47. Wells GA, Shea B, Connell DO, et al. The Newcastle-Ottawa Scale (NOS) for assessing the quality of nonrandomised studies in metaanalyses. http://www.ohri.ca/programs/clinical_epidemiology/oxford. asp

48. Walensky RP, Reichmann WM, Arbelaez C, et al. Counselor- versus provider-based HIV screening in the emergency department: results from the universal screening for HIV infection in the emergency room (USHER) randomized controlled trial. Ann Emerg Med 2011;58:S126-32.e1-4.

49. Anaya HD, Hoang T, Golden JF, et al. Improving HIV screening and receipt of results by nurse-initiated streamlined counseling and rapid testing. J Gen Intern Med 2008;23:800-7.

50. Malonza IM, Richardson BA, Kreiss JK, et al. The effect of rapid HIV-1 testing on uptake of perinatal HIV-1 interventions: a randomized clinical trial. AIDS 2003:17:113-18.

51. Lugada $\mathrm{E}$, Levin J, Abang B, et al. Comparison of home and clinic-based HIV testing among household members of persons taking antiretroviral therapy in Uganda: results from a randomized trial. J Acquir Immune Defic Syndr 2010;55:245-52.

52. Spielberg F, Branson BM, Goldbaum GM, et al. Choosing HIV counseling and testing strategies for outreach settings. Epidemio/ Soc Sci 2005;38:348-55.

53. White DA, Tran T, Dideum PJ, et al. Physician-initiated rapid HIV testing in an urban emergency department: comparison of testing 
using a point-of-care versus a laboratory model. Ann Emerg Med 2011;58:S53-9.

54. Liang TS, Erbelding E, Jacob CA, et al. Rapid HIV testing of clients of a mobile STD/HIV clinic. AIDS Patient Care STDs 2005;19:253-7.

55. Huebner DM, Binson D, Dilworth SE, et al. Rapid vs. standard HIV testing in bathhouses: what is gained and lost? AIDS Behav 2010:14:688-96.

56. Appiah LT, Havers F, Gibson J, et al. Efficacy and acceptability of rapid, point-of-care HIV testing in two clinical settings in Ghana. AIDS Patient Care STDs 2009;23:365-9.

57. Sweat M, Morin S, Celentano D, et al. Increases in HIV testing and case detection from NIMH Project Accept (HPTN 043) among 16-32 year olds: a randomized community-based intervention in Tanzania, Zimbabwe, and Thailand. Lancet Infect Dis 2012;11:525-32.

58. Read TRH, Hocking JS, Bradshaw CS, et al. Provision of rapid HIV tests within a health service and frequency of HIV testing among men who have sex with men: randomised controlled trial. BMJ 2013;347:f5086.

59. Coates TJ, Kulich M, Celentano DCD, et al. Effect of community-based voluntary counselling and testing on HIV incidence and social and behavioural outcomes (NIMH Project Accept; HPTN 043): a cluster-randomised trial. Lancet Glob Health 2014:2:e267-77.

60. Coates T, Eshleman SH, Chariyalertsak S, et al.; the H 043 PAST Community-level reductions in estimated HIV incidence: HIV Prevention Trials Network 043, Project Accept. Conference on Retroviruses and Opportunistic Infections. Atlanta, 2013. http://www. retroconference.org/2013b/Abstracts/47715.htm (accessed 18 Apr 2013).

61. Guyatt GH, Oxman AD, Kunz R, et al. Going from evidence to recommendations. BMJ 2008;336:1049-51.
62. Guyatt G, Oxman AD, Akl EA, et al. GRADE guidelines: 1. Introduction-GRADE evidence profiles and summary of findings tables. J Clin Epidemiol 2011;64:383-94.

63. Guyatt GH, Oxman AD, Kunz R, et al. GRADE guidelines: 7. Rating the quality of evidence-inconsistency. J Clin Epidemiol 2011;64:1294-302.

64. Vermund SH, Wilson CM. Barriers to HIV testing-where next. Lancet 2002;360:1186-7.

65. Suthar $A B$, Ford $N$, Bachanas $\mathrm{PJ}$, et al. Towards universal voluntary HIV testing and counselling: a systematic review and meta-analysis of community-based approaches. PLoS Med 2013;10:e1001496.

66. Cherutich P, Kaiser R, Galbraith J, et al. Lack of knowledge of HIV status a major barrier to HIV prevention, care and treatment efforts in Kenya: results from a nationally representative study. PIoS ONE 2012;7:e36797.

67. Wang Y, Guo J, Lu W. Effects of rapid versus standard HIV voluntary counselling and testing on reception rate: a meta-analysis. Int J STD AIDS 2014

68. Noyes J, Gough D, Lewin S, et al. A research and development agenda for systematic reviews that ask complex questions about complex interventions. J Clin Epidemiol 2013;66:1262-70.

69. Craig P, Dieppe $\mathrm{P}$, Macintyre S, et al. Developing and evaluating complex interventions: the new Medical Research Council guidance. BMJ 2008;337:a1655

70. De Cock KM, Bunnell R, Mermin J. Unfinished business-expanding HIV testing in developing countries. N Engl J Med 2006;354:440-2.

71. World Health Organization (WHO). Delivering HIV test results and messages for re-testing and counselling in adults. 2010. http:// whqlibdoc.who.int/publications/2010/9789241599115 eng.pdf

72. Banerfee A, Duflo E. Poor economics: a radical thinking of the way to fight global poverty. New York, NY: Public Affairs, 2012. 